\title{
EMSY Gene Amplification
}

National Cancer Institute

\section{Source}

National Cancer Institute. EMSY Gene Amplification. NCI Thesaurus. Code C131453.

A molecular genetic abnormality indicating the presence of multiple copies of the EMSY gene. 